\title{
Development and simulation of the Institute of ionosphere measuring complex energy consumption
}

\author{
A. Gapon \\ National Technical University \\ "Kharkiv Polytechnic Institute" \\ Ukraine \\ E-mail: gaponold54@gmail.com
}

\author{
O. Yevseienko \\ National Technical University \\ "Kharkiv Polytechnic Institute" \\ Ukraine \\ E-mail: olegyevseienko@gmail.com
}

\author{
O. Grib \\ National Technical University \\ "Kharkiv Polytechnic Institute" \\ Ukraine \\ E-mail: ae_khpi@ukr.net
}

\author{
S. Kozlov \\ National Technical University \\ "Kharkiv Polytechnic Institute" \\ Ukraine \\ E-mail: ksser300@gmail.com
}

\author{
O. Levon \\ National Technical University \\ "Kharkiv Polytechnic Institute" \\ Ukraine \\ E-mail: elena_levon@ukr.net
}

\begin{abstract}
The work is devoted to solving an urgent problem - the development of a computer model of the energy consumption system of the Institute of the ionosphere of the National Academy of Sciences and the Ministry of Education and Science of Ukraine in order to solve the problem of increasing the energy efficiency of the measuring complex. The power supply system of the complex is described, a generalized structural diagram of the loads powerful consumers of electricity is presented. The graphs characterizing the energy consumption of individual powerful loads are presented, the problem of compensating the reactive power of loads is shown. The adequacy of the developed model is confirmed by the coincidence of the shape and values of the experimentally obtained characteristics on loads with the characteristics of the model. The model adequacy was assessed by the variance of feedback deviations from the system mean. The results obtained confirmed the possibility of using the developed Matlab-model of the energy consumption system of the measuring complex for creating and testing on the model of an energy-efficient power supply system, which will ensure the stable operation of scientific equipment for the implementation of research programs of the NAS of Ukraine.
\end{abstract}

Keywords - power supply system, power consumption, energy efficiency, average power consumption.

\section{PROBLEM STATEMENT}

The Institute of ionosphere is one of the world's largest research institutes that studies the ionized part of the atmosphere [1]. The research part of the institute consists of transmitter channels, distribution network, three pavilions, the main load of which consists of: distillers, heating boiler, STS stabilizer, pumps of distiller and raw water circuits, converters, antenna, receiver.

Ionosphere studies are conducted at intervals of two to four studies per month. One test takes five days in a row. In summer, the consumption for one test is about 16060 $\mathrm{kW}$, and in winter about $18720 \mathrm{~kW}$. Due to the high cost of $1 \mathrm{~kW}$ of electricity, the annual research costs the institute a considerable amount.
In today's world, in order to save electricity, there is a tendency to abandon the use of electricity in favor of alternative sources such as sun, wind, water. Due to their geographical location and temperate continental climate, Ukraine and Kharkiv have a total annual level of solar radiation at the level of $1200 \mathrm{kWh} / \mathrm{m} 2$.

The Institute of Ionosphere territorially has free space that can be used to accommodate solar panels and wind turbines, with their subsequent integration into a smart SmartGrid power system. The use of solar panels, as well as batteries with a large number of charge / discharge cycles with the ability to return energy to the industrial network can increase the energy efficiency of the system [2-4].

\section{PURPOSE AND OBJECTIVES OF THE RESEARCH}

The purpose of the work is the development of a computer model of the Institute of ionosphere energy consumption system of the National Academy of Sciences and the Ministry of Education and Science of Ukraine in order to solve the problem of increasing the energy efficiency of the measuring complex.

\section{PRESENTATION OF THE BASIC MATERIAL}

The model of the Ionosphere Research Institute consists of three pavilions, a cooling circuit, and a transmitter. Pavilion 1 contains an ionosonde, a heating system, computers, workplaces and air conditioners. Pavilion 2 heating system, receiver, full swing antenna motors, air conditioning unit. In pavilion 3 there are distillers, a stabilizer, household appliances, a heating system, pumps for distiller circuits. The cooling circuit consists of raw water pumps, cooling water fans. The transmitter includes 5 channels, each of with has a power of $50 \mathrm{~kW}$. During the tests, only 2 channels out of 5 are switched on simultaneously. A $1 \mathrm{MW}$ transformer with a voltage of 10 / $0.4 \mathrm{kV}$ is used at the entrance to the system. In parallel, a $560 \mathrm{~kW}$ transformer with a voltage of $10 / 0.4 \mathrm{kV}$ is connected to it, which is used as a safety net if the main transformer is faulty. Each channel of the transmitter uses 
its own separate transformer with a power of $250 \mathrm{~kW}$ and a voltage of $10 / 1.2 \mathrm{kV}$ on the windings.

The structural scheme of connection of energy consumers of the Institute is shown in the Fig. 1.
The electrical indicators of the devices are given in table 1 .

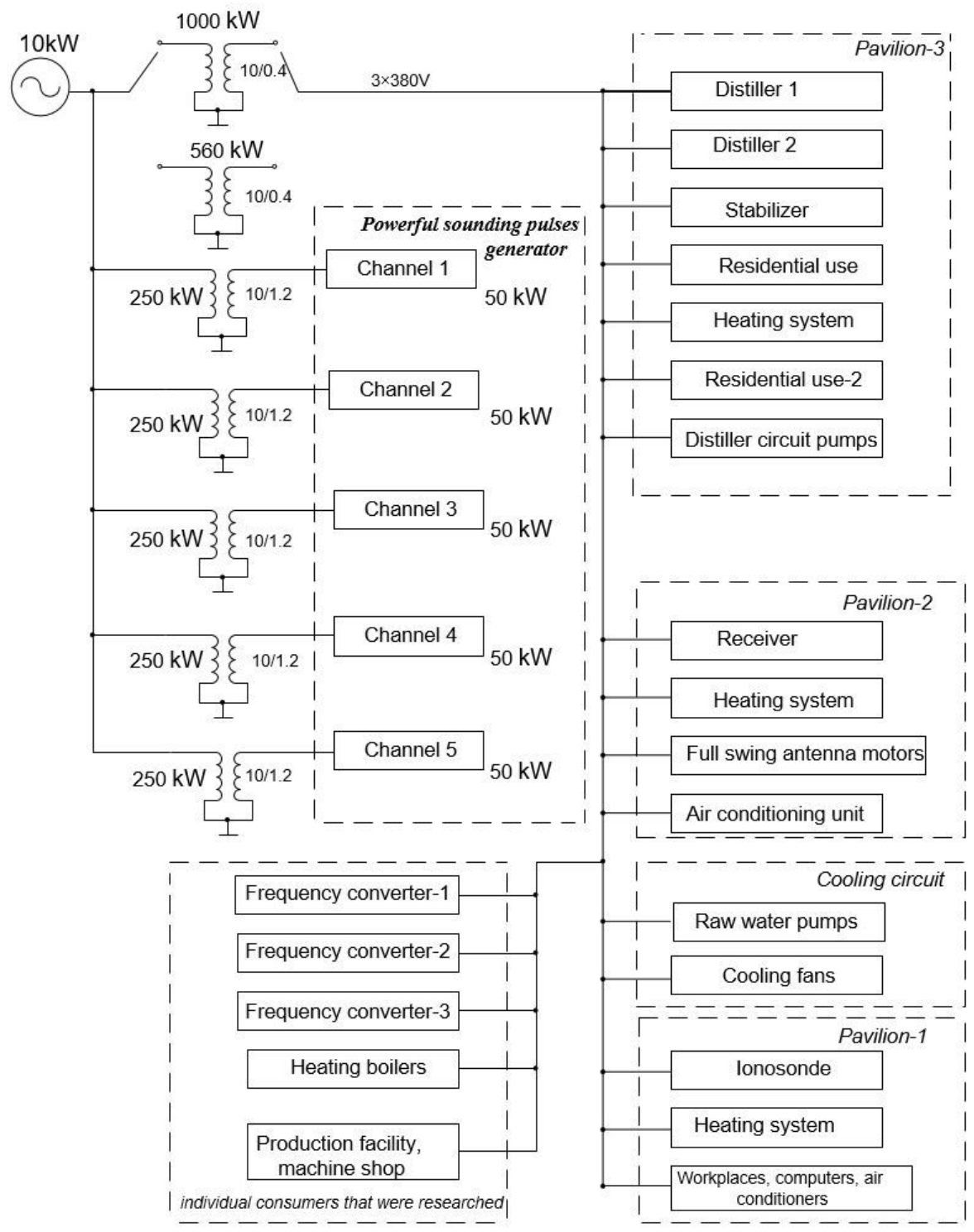

Fig. 1. The structural scheme of connection of energy consumers of the Institute of ionosphere

The meter-range radar radio transmitter (shaper) generates, amplifies and transmits powerful probing pulses and is built on a two-channel circuit, each channel of which is a pulse transmitter that generates high-frequency probing pulses at a frequency of $158 \mathrm{MHz}$. The main parameters of the shaper (Channels 1 - 5):

- pulse power at the output $\mathrm{Pi}>2 \mathrm{MW}$,

- $\quad$ the length of the emitted pulses $\mathrm{Ti}=800 \mu \mathrm{s}$,

- $\quad$ pulse repetition frequency $\mathrm{Fi}=24.4 \mathrm{~Hz}$.

The modulation device is designed to power the transmitter device and provides pulsed anode voltage to the following channels and blocks of the transmitter device: III stage, II stage, I stage, preamplifier and oscillator frequency generator. The modulation device provides a pulse power of $4.26 \mathrm{MW}$ at a voltage of $29 \mathrm{kV}$ at an equivalent load of 200 ohms. When working on the generator, the modulation device provides the following maximum voltage values:

$$
\begin{array}{ll}
\text { - } & \text { III cascade - } 29 \mathrm{kV} \\
\text { - } & \text { II cascade }-23 \mathrm{kV} \\
\text { - } & \text { I cascade }-7.5 \mathrm{kV}
\end{array}
$$

Based on the structural diagram and initial data, a model has been developed, which consists of a supply unit, pavilion 3, a transmitter, a cooling circuit, converters, pavilion 2, pavilion 1 (Fig. 2). 
МІЖНАРОДНИЙ ЖУРНАЛ «СВІТЛОТЕХНІКА ТА ЕЛЕКТРОЕНЕРГЕТИКА»

A. Gapon, O. Grib, S. Kozlov, O. Yevseienko, O. Levon Вип.58, №02.

TABLE I. INFORMATION ON MODELED COMPONENTS

\begin{tabular}{|c|c|c|}
\hline Component name & $\begin{array}{l}\text { Power, } \\
\text { kW }\end{array}$ & $\begin{array}{c}\text { Phase shift } \\
\text { angle }\end{array}$ \\
\hline \multicolumn{3}{|c|}{ Pavilion 1} \\
\hline Ionosonde & 0.3 & 10 \\
\hline Heating system & 6 & 0 \\
\hline $\begin{array}{l}\text { Workplaces, computers, air } \\
\text { conditioners }\end{array}$ & 0.5 & 10 \\
\hline \multicolumn{3}{|c|}{$\begin{array}{l}\text { Pavilion 2 } \\
\end{array}$} \\
\hline Heating system & 6 & 0 \\
\hline Receiver & 5 & $20 / 0 / 10$ \\
\hline Full swing antenna motors & 20 & 30 \\
\hline Air conditioning unit & 10 & 0 \\
\hline \multicolumn{3}{|c|}{ Pavilion 3} \\
\hline Distiller 1 & 55 & 0 \\
\hline Distiller 2 & 55 & 0 \\
\hline Stabilizer CTC 63/0.5 & 63 & $55.5 / 30 / 30$ \\
\hline Appliances for residential use 1 & 4.2 & 40 \\
\hline Heating system & 60 & 0 \\
\hline Appliances for residential use 2 & 3.8 & 20 \\
\hline Distiller circuit pumps & 10.5 & 0 \\
\hline \multicolumn{3}{|c|}{ Cooling circuit } \\
\hline Raw water pumps & 23 & 20 \\
\hline Cooling funs & 9 & 54 \\
\hline \multicolumn{3}{|c|}{ Converters } \\
\hline Converter 1 & 30 & 60 \\
\hline Converter 2 & 30 & 60 \\
\hline Converter 3 & 50 & 60 \\
\hline Heating system 1 & 6 & 0 \\
\hline Heating system 2 & 6 & 0 \\
\hline \multicolumn{3}{|c|}{ Transmitters } \\
\hline Channel 1 & 50 & 53 \\
\hline Channel 2 & 50 & 53 \\
\hline Channel 3 & 50 & 53 \\
\hline Channel 4 & 50 & 53 \\
\hline Channel 5 & 50 & 53 \\
\hline
\end{tabular}

Three-Phase Source

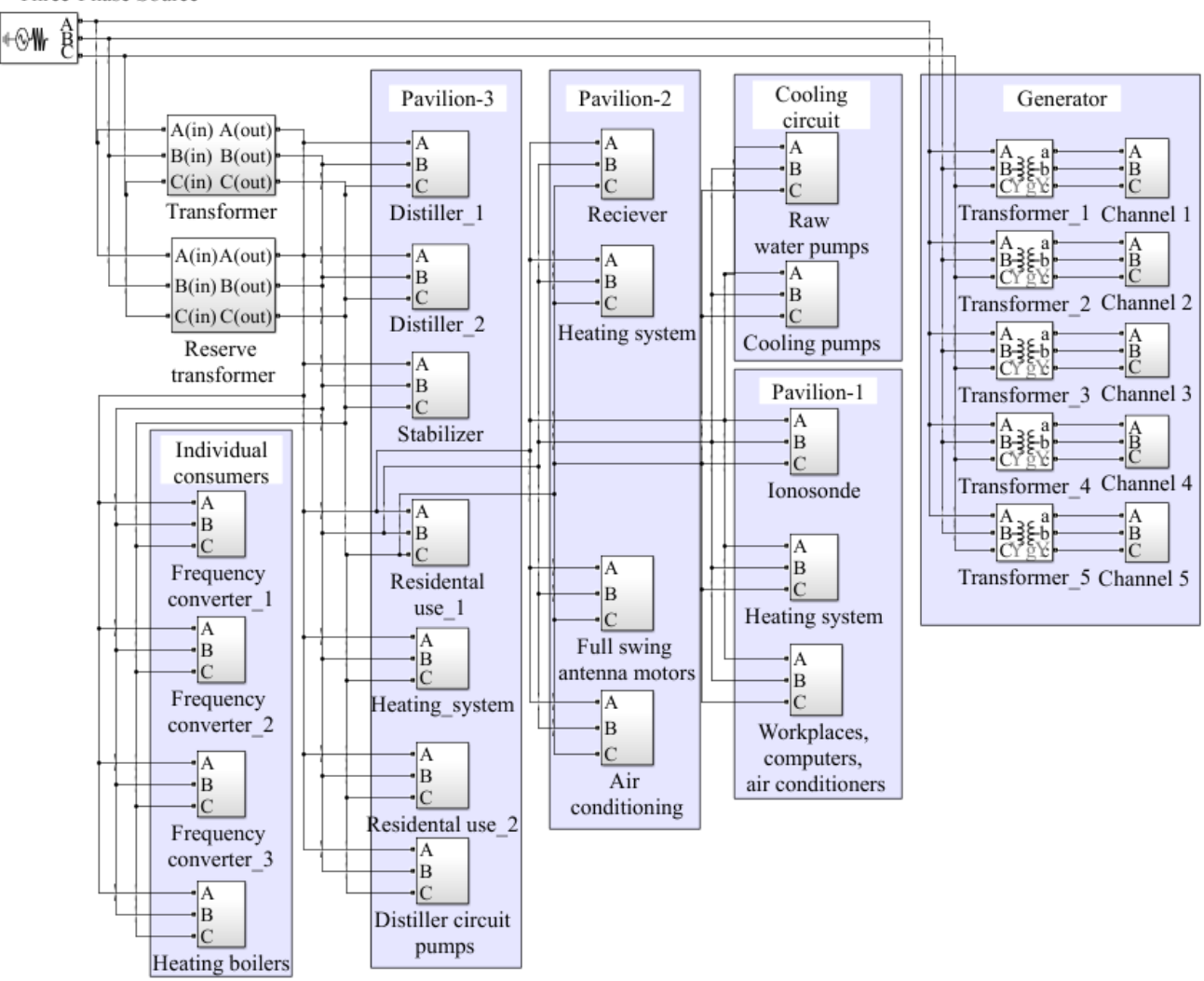

Fig. 2. The Matlab-model of connection of energy consumers of the Institute of ionosphere 


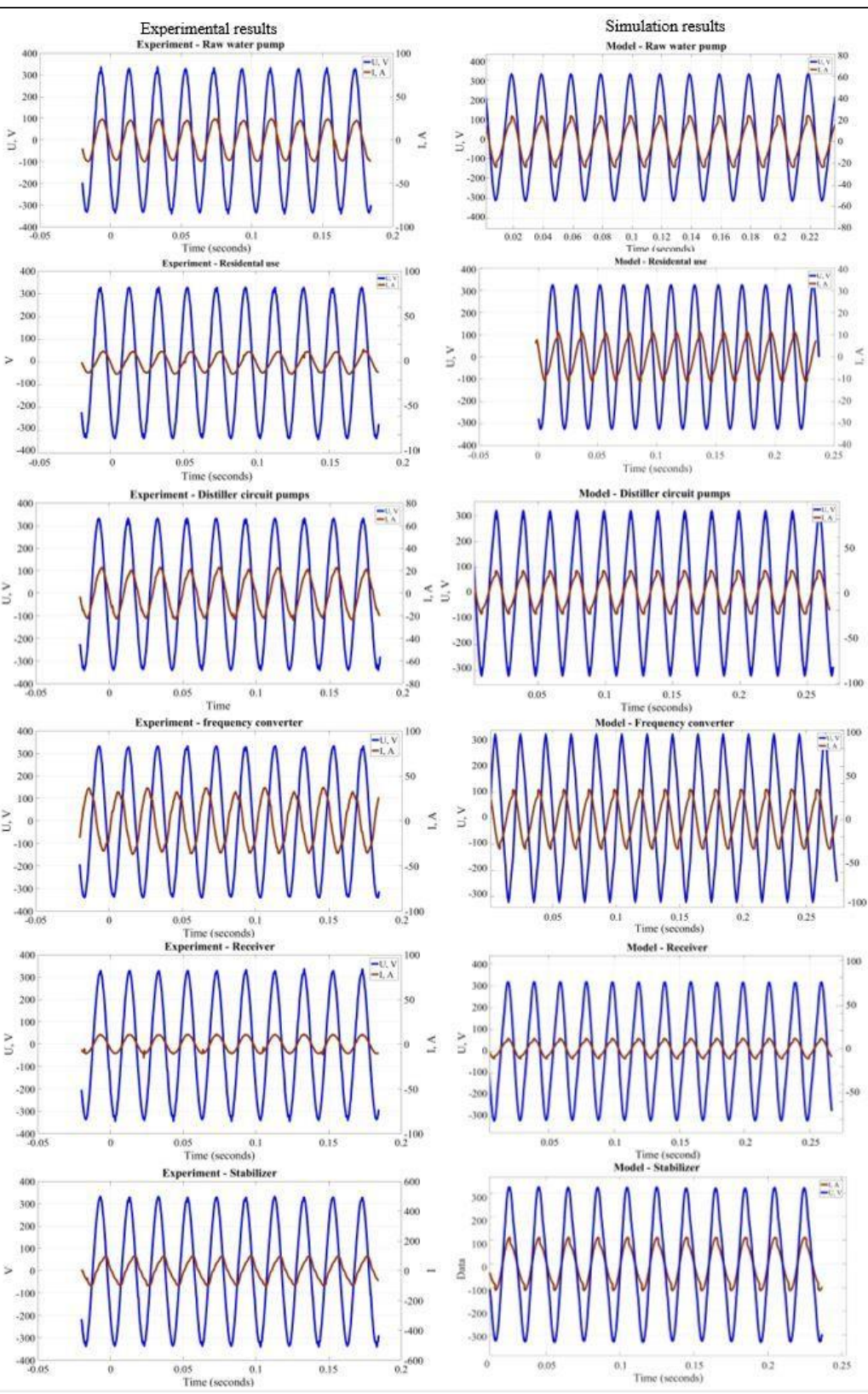

Fig. 3. Experiment and simulation results

Experimental data were taken at the connection points of each consumer. The oscillograms of currents and voltages of some consumers are shown in Fig. 3. The data of the graphs given on the oscillograms allow to estimate the adequacy of the developed Matlab-model of the power supply system of the measuring complex. The procedure for assessing the adequacy of the developed model is based on the comparison of measurements on a real system of experimental results on the model, which is carried out on the average values of the responses of the model and the system. The given data testify to a considerable share of reactive power in the mode of inclusion of the radio equipment. Irregular energy consumption, the presence of a significant share of the reactive component of energy consumption make such facilities commercially unattractive to energy companies, in modern conditions can lead to either significant fines or even shutdown.
The next step is to propose a methodology to increase the commercial attractiveness of research facilities such as the Institute of ionosphere, which aims to reduce the difference in energy consumption during the experiment and a simple and significant reduction in the reactive component. The proposed technique will be based on the construction of a mathematical model of the energy complex of the radio range and the study of its dynamic, frequency and energy properties. The methodology provides for such steps as the division of all consumers in the facility into permanent (conditional), and those that operate in pulse mode. For the latter group of consumers, it is proposed to use rechargeable batteries as a damper, which is an active load for the energy supplier, connected at night, and for the equipment - a provider of continuous action during the experiment. In works [5 - 8], devoted to the decision of problems of improvement of electric power quality of a power supply network, the basic principles and approaches to the decision of a problem of quality of the electric power of a power supply network are formulated. 
A. Gapon, O. Grib, S. Kozlov, O. Yevseienko, O. Levon Вип.58, №02.

At the same time, the analysis of scientific works shows that a number of problematic issues need further study, there is a need to improve existing scientific and methodological approaches to determining the effectiveness of the operation of various types of measures that apply to a particular object.

\section{CONCLUSIONS}

After obtaining experimental data and analyzing the energy consumption of the measuring complex of the Institute of ionosphere of the National Academy of Sciences and the Ministry of Education and Science of Ukraine, a model of the energy consumption system of the complex was developed. The obtained modeling results indicate the adequacy of the developed model and the possibility of using the model in the development of methods to improve the efficiency of operation of the whole complex. According to the results of the analysis of the nature of the loads, it is determined that the loads include a reactive component, which can be eliminated through the use of filter-compensating devices.

\section{REFERENCES}

[1] L. Emelyanov and T. Zhivolup, "History of the development of IS radars and founding of the Institute of Ionosphere in Ukraine," History of Geo- and Space Sciences, Vol. 4, pp. 7-17, 2013
[2] S. Kozlov, "Optimization of power supply of the research complex of the Institute of the ionosphere," Materials of the 1st International Scientific and Technical Conference "Actual problems of automation and instrumentation," pp. 26-27, 2017.

[3] A. Gapon, S. Kozlov and Y. Svetlichnaya, "Optimization of the parameters of power plants of the radio range of the institute of ionosphere NAS of Ukraine Materials of the 2nd International Scientific and Technical Conference "Actual problems of automation and instrumentation," pp. 24-25, 2018.

[4] S. Kozlov, "Analysis of energy consumption regimes of the incoherent scattering complex of the Institute of Ionosphere of NAS and MES of Ukraine," Bulletin of the National Technical University "KhPI". Series: Radiophysics and ionosphere, № 43, pp. 51-54, 2018

[5] O. Trofimenko , S. Voitko "Functioning, strategic development and regulation of renewable energy": monograph, Alfa Reklama, 178 pp., 2014.

[6] O. Levon, "Semiconductordual two-channel regulated compensator of inactive components of the total power": $\mathrm{Ph}$.Dr. tech. sci. diss.: 05.09.12 / NTU "KhPI", Kharkiv, 200 Pp., 2015. (Rus.)

[7] V. Ivanov and V. Sokolov "Consumption modes and power quality of power supply systems of industrial enterprises," Energoatomizdat, 336 pp., 1987.

[8] J. Dixon, Y. del Valle, M. Orchard, M. Ortúzar, L. Morán and C. Maffrand, "A Full Compensating System for General Loads, Based on a combination of Thyristor Binary Compensator and a PWMIGBT Active Power Filter," IEEE Trans. Industrial Electronics, Vol.50, No. 5, pp. 982-989, 2003.

\title{
Розробка та моделювання системи енергоспоживання вимірювального комплексу Інститута іоносфери
}
A.I. Гапон
О.Г. Гриб
С.С. Козлов

Національний технічний університет Національний технічний університет Національний технічний університет

"Харківський політехнічний інститут", Україна

\section{О.М. Євсеєнко}

Національний технічний університет

"Харківський політехнічний інститут", Україна
"Харківський політехнічний інститут”, Україна
"Харківський політехнічний інститут", Україна

\author{
О.О. Левон \\ Національний технічний університет \\ "Харківський політехнічний \\ інститут", Україна
}

Роботу присвячено вирішенню нагальної проблеми - розробці комп'ютерної моделі системи енергоспоживання Інституту іоносфери НАН та МОН України 3 метою вирішення проблеми підвищення енергоефективності вимірювального комплексу. Описано систему електропостачання комплексу, представлено узагальнену структурну схему навантажень - потужних споживачів електроенергії, описано характер навантаження 3 точки зору якості електроенергії. Визначено, що найбільш потужний споживач електроенергії вимірювального комплексу - формувач потужних зондуючих імпульсів, який здійснює генерацію, посилення i передачу потужних зондуючих імпульсів $\mathrm{i}$ будується за дво- або чотириканальною схемою, кожен канал якої є імпульсний передавач, що генерує високочастотні зондуючі імпульси. Експериментальні дані, представлені у роботі, показали, що режим електроспоживання Інституту іоносфери характеризусться значною сквапністю. Представлено графіки, шо характеризують споживання енергії окремими потужними навантаженнями, показано проблему компенсації реактивної потужності навантажень. Адекватність розробленої моделі підтверджусться збігом форми та значень експериментально отриманих характеристик на навантаженнях 3 характеристиками моделі. Адекватність моделі оцінювалась за середнім значенням відгуків моделі і системи. Отримані результати підтвердили можливість використання розробленої Маtlab-моделі системи енергоспоживання вимірювального комплексу для створення та випробування на моделі енергоефективної системи електропостачання, що забезпечить стабільну роботу наукового обладнання для впровадження дослідницьких програм НАН України. Зроблено висновки щодо можливості підвищення якості електроенергії живлення потужного споживача за допомогою фільтрокомпенсуючих пристроїв, що дозволяє зменшити втрати енергії та поліпшити електромагнітну сумісність вимірювального комплексу Інститута іоносфери 3 мережею живлення. Проаналізовано літературу щодо створення та застосування багатофункціональних енергоефективних компенсаторів неактивних складових повної потужності, що дозволяють успішно вирішувати задачу компенсації реактивної потужності, шо генерусться або споживасться навантаженням, фільтрації вищих гармонік струму.

Ключові слова - система електропостачання, енергоспоживання, енергоефективність, реактивна потужність. 